\title{
Influence of oxygen on asexual blood cycle and susceptibility of Plasmodium falciparum to chloroquine: requirement of a standardized in vitro assay
} Sébastien Briolant*1, Philippe Parola ${ }^{1,2}$, Thierry Fusaï ${ }^{1}$, Marilyn MadametTorrentino $^{3}$, Eric Baret ${ }^{1}$, Joël Mosnier ${ }^{1}$, Jean P Delmont ${ }^{2}$, Daniel Parzy ${ }^{3}$, Philippe Minodier ${ }^{4}$, Christophe Rogier ${ }^{1}$ and Bruno Pradines ${ }^{1}$

\author{
Address: ${ }^{1}$ Unité de Recherche en Biologie et Epidémiologie Parasitaires, Institut de Médecine Tropicale du Service de Santé des Armées, Marseille, \\ France, ${ }^{2}$ Service de Maladies Infectieuses et Tropicales, Hôpital Nord, Marseille, France, ${ }^{3}$ Unité de Recherche en Pharmacologie et Physiopathologie \\ Parasitaires, Institut de Médecine Tropicale du Service de Santé des Armées, Marseille, France and ${ }^{4}$ Service de Pédiatrie, Hôpital Nord Marseille, \\ France \\ Email: Sébastien Briolant* - sbriolant@wanadoo.fr; Philippe Parola - philippe.parola@medecine.univ-mrs.fr; \\ Thierry Fusaï - thierry.fusai@free.fr; Marilyn Madamet-Torrentino - marylin.torrentino@freesbee.fr; Eric Baret - baret.eric@neuf.fr; \\ Joël Mosnier - joel.mosnier@cegetel.net; Jean P Delmont - jpdelmont@mail.ap-hm.fr; Daniel Parzy - d.parzy@free.fr; \\ Philippe Minodier - hilippe.minodier@mail.ap-hm.fr; Christophe Rogier - christophe.rogier@wanadoo.fr; \\ Bruno Pradines - bruno.pradines@free.fr \\ * Corresponding author
}

Published: 16 April 2007

Malaria Journal 2007, 6:44 doi:10.1 186/1475-2875-6-44

This article is available from: http://www.malariajournal.com/content/6/l/44

(c) 2007 Briolant et al; licensee BioMed Central Ltd.

This is an Open Access article distributed under the terms of the Creative Commons Attribution License (http://creativecommons.org/licenses/by/2.0), which permits unrestricted use, distribution, and reproduction in any medium, provided the original work is properly cited.
Accepted: 16 April 2007
Received: 29 January 2007

\begin{abstract}
Objective: The main objective of this study was to assess the influence of gas mixtures on in vitro Plasmodium falciparum growth and $50 \%$ inhibitory concentration $\left(\mathrm{IC}_{50}\right)$ for chloroquine.
\end{abstract}

Methods: The study was performed between February 2004 and December 2005. I36 Plasmodium falciparum isolates were used to evaluate gas mixtures effect on $\mathrm{IC}_{50}$ for chloroquine by isotopic microtest. The oxygen effect on asexual blood cycle of 3D7 and W2 clones was determined by thin blood smears examination and tritiated hypoxanthine uptake.

Results: From $5 \% \mathrm{O}_{2}$ to $21 \% \mathrm{O}_{2}$ conditions, no parasiticide effect of $\mathrm{O}_{2}$ concentration was observed in vitro on the clones 3D7 and W2. A parasitostatic effect was observed during the exposure of mature trophozoïtes and schizonts at $21 \% \mathrm{O}_{2}$ with an increase in the length of schizogony. The chloroquine $\mathrm{IC}_{50}$ at $10 \% \mathrm{O}_{2}$ were significantly higher than those at $21 \% \mathrm{O}_{2}$, means of $173.5 \mathrm{nM}$ and $121.5 \mathrm{nM}$ respectively $(\mathrm{p}<0.000 \mathrm{I})$. In particular of interest, among the 63 isolates that were in vitro resistant to chloroquine $\left(\mathrm{IC}_{50}>100 \mathrm{nM}\right)$ at $10 \% \mathrm{O}_{2}, 17$ were sensitive to chloroquine $\left(\mathrm{IC}_{50}<100 \mathrm{nM}\right)$ at $21 \% \mathrm{O}_{2}$.

Conclusion: Based on these results, laboratories should use the same gas mixture to realize isotopic microtest. Further studies on comparison of isotopic and non-isotopic assays are needed to establish a standardized in vitro assay protocol to survey malaria drug resistance. 


\section{Background}

Drug resistance of Plasmodium falciparum, the most deadly human malaria parasite with nearly 500 millions of new clinical cases each year [1], makes malaria control more difficult $[2,3]$. There are basically three approaches to the assessment of the antimalarial drug susceptibility of $P$. falciparum: in vivo assays as defined by the World Health Organization [4], in vitro assays and molecular markers of resistance [5].

In a number of laboratories surveying malaria drug resistance, in vitro tests are performed using the uptake of a radiolabelled nucleic acid precursor $\left[{ }^{3} \mathrm{H}\right]$-hypoxanthine [6] as a marker of parasite growth. Others methods can be used: the WHO schizont maturation tests by optical microscopy (Mark III) with pre-dosed plates [7], which was based on the method of Rieckmann et al [8] and of Wernsdorfer [9], a flow cytometric analysis of propidium iodide incorporation into parasite, which permits a stage-specific evaluation of antimalarial compounds [10], and colorimetric assays with the measurement of Histidine Rich Protein II (HRP2) by an enzyme-linked immunosorbent assay (ELISA) $[11,12]$ and the DELI-microtest (Double-site Enzyme-linked Lactate dehydrogenase Immunosorbent assay) $[13,14]$.

Many factors can influence the results of the chemosusceptibility tests [15]: the initial parasitaemia, the haematocrit, the time of incubation, the time point when $\left[{ }^{3} \mathrm{H}\right]-$ hypoxanthine is added, the use of serum substitutes and the gas mixture. Laboratories using isotopic microtest to monitor drug resistance work at different oxygen tensions: $3 \% \mathrm{O}_{2}[10], 5 \% \mathrm{O}_{2}[11,12], 10 \% \mathrm{O}_{2}[16]$, in candle jars $[13,14]$ (which corresponds to approximately $15 \% \mathrm{O}_{2}$ [17]) and $21 \% \mathrm{O}_{2}$ [15] (in $\mathrm{CO}_{2}$ incubators). WHO recommends the use of a candle jar in their in vitro microtests (Mark III). But all have adopted the same threshold for the resistance to antimalarial compounds under different oxygen tensions. The aim of this study was to evaluate the influence of oxygen on the asexual blood cycle and the in vitro chemosusceptibility of $P$. falciparum to chloroquine in order to contribute to the establishment of a standardized in vitro assay protocol.

\section{Methods}

\section{Isolates of P. falciparum}

Between February 2004 and December 2005, 136 P. falciparum isolates were obtained from patients attending the North Hospital in Marseille [18] (France). Venous blood was collected into Vacutainer ACD tubes (Becton Dickinson, Rutherford, NJ) before treatment and transported at $4{ }^{\circ} \mathrm{C}$ to the laboratory in Marseilles, that is associated to the French National Malaria Reference Center. Thin blood smears were stained using a RAL kit (Réactifs RAL, Paris, France) and examined to determine parasite density. Sam- ples with parasitaemia ranging from $0.01 \%$ to $6.2 \%$ were used to test drug sensitivity. Parasitized erythrocytes were washed three times in RPMI 1640 medium (Invitrogen, Paisley, United Kingdom). If parasitaemia exceeded $0.8 \%$, infected erythrocytes were diluted to $0.5-0.8 \%$ with uninfected erythrocytes and resuspended in culture medium to a haematocrit of $1.5 \%$. Susceptibility to chloroquine was determined after suspension in RPMI 1640 medium. The suspensions were supplemented with $10 \%$ human serum (AbCys, Paris, France) and buffered with $25 \mathrm{mM}$ HEPES (Sigma, St. Louis, MO) and $25 \mathrm{mM} \mathrm{NaHCO}_{3}$ (Sigma). Isolates were used for 60-hr experiments at two different gas mixtures under $10 \% \mathrm{O}_{2}, 5 \% \mathrm{CO}_{2}, 85 \% \mathrm{~N}_{2}$ in a $\mathrm{CO}_{2}$ water jacketed incubator series II (Model 3141, Forma Scientific, Inc.) or $21 \% \mathrm{O}_{2}, 5 \% \mathrm{CO}_{2}, 74 \% \mathrm{~N}_{2}$ in a $\mathrm{CO}_{2}$ incubator (Model MCO-17 AIC, Sanyo).

\section{Parasite clones}

Chloroquine sensitive 3D7 clone and chloroquine resistant W2 clone (MR4 Resource Center) were used in this study. They were maintained in continuous culture as previously described [19] at $6 \%$ haematocrit using type $\mathrm{O}+$ (3D7) or type A+ (W2) human erythrocytes in the same conditions as described above at $37^{\circ} \mathrm{C}$ under a $5 \% \mathrm{CO}_{2}$, $5 \% \mathrm{O}_{2}, 90 \% \mathrm{~N}_{2}$ gas mixture and a humidity of $95 \%$. Culture medium was changed every day, viability and parasitaemia of cultured parasites were calculated by light microscopy analysis of blood smear stained with RAL $^{\oplus}$ 555 (Réactifs RAL, France), (5,000 erythrocytes counted per blood smear). Blood smear pictures were performed using a digital camera (Digital Camera DXM 1200, Nikon), and analyzed with the software Lucia 4.8 (Nikon). Parasite synchronization was performed by sorbitol treatment (D-Sorbitol, ICN Biomedicals) as previously described [20]. To obtain tightly synchronized cultures, two sorbitol treatments were carried out $12 \mathrm{~h}$ apart. Approximately $48 \mathrm{~h}$ after the initial synchronization, the cultures were synchronized again to eliminate any residual schizonts. Clonality was verified every month using PCR genotyping of polymorphic genetic markers (msp1, msp2 and microsatellite loci $[21,22]$ ).

\section{Drug}

Chloroquine diphosphate was obtained from Sigma Chemical Co. (St. Louis, Mo, U.S.A.). Two-fold serial dilutions of chloroquine were prepared in sterile, distilled water. Final concentrations ranging from $5 \mathrm{nM}$ to 3200 $\mathrm{nM}$ were distributed in triplicate into Falcon 96-well flatbottom plates (Becton Dickinson, Franklin Lakes, N.J.), which were dried.

\section{Oxygen effects on asexual blood cycle of $P$. falciparum}

Synchronous cultures of 3D7 or W2 were divided in three subcultures at 2\% initial parasitaemia for 3D7 and 0.5\% for W2 and 3\% haematocrit under three different oxygen 
tensions $5 \% \mathrm{O}_{2}, 10 \% \mathrm{O}_{2}$ and $21 \% \mathrm{O}_{2}$ in three different experiments with duplicates. Culture mediums were not replaced during the experiments. Blood smears were carried out at different times to evaluate parasitaemia and percentages of different stages of parasite $(5,000$ erythrocytes were counted per blood smear in blind by two different examiners). The same experiments (three different experiments with duplicates) were undertaken with 3D7 parasites with only ten hours exposures of rings stages, trophozoïtes stages or schizonts stages under $21 \% \mathrm{O}_{2}, 5 \%$ $\mathrm{CO}_{2}, 74 \% \mathrm{~N}_{2}$ gas mixture and under $5 \% \mathrm{O}_{2}, 5 \% \mathrm{CO}_{2}$, $90 \% \mathrm{~N}_{2}$ gas mixture in a $\mathrm{CO}_{2}$ water jacketed incubator series II (Model 3131, Forma Scientific, Inc.) during the rest of the cycle to assess a stage susceptibility of oxygen effect.

\section{Tritiated hypoxanthine uptake}

$200 \mu \mathrm{l}$ of the suspension of no parasitized and parasitized erythrocytes (1\% parasitaemia, $2 \%$ haematocrit) was distributed in 96-well plates (three different experiments with six measurements). Parasite growth was assessed by adding $1 \mu \mathrm{Ci}$ of $\left[{ }^{3} \mathrm{H}\right]$-hypoxanthine with a specific activity of $14.1 \mathrm{Ci} / \mathrm{mmol}$ (Perkin Elmer, Meriden, NJ) to each well. Plates were incubated for different periods and at different parasites stages at $37^{\circ} \mathrm{C}$ under $21 \% \mathrm{O}_{2}, 5 \% \mathrm{CO}_{2}$, $74 \% \mathrm{~N}_{2}$ or $10 \% \mathrm{O}_{2}, 5 \% \mathrm{CO}_{2}, 85 \% \mathrm{~N}_{2}$ gas mixture and a humidity of $95 \%$. Duplicate wells were used to make thin blood smears to evaluate parasitaemia and parasite stages. Immediately after incubation the plates were frozen and then thawed to lyse erythrocytes. The content of each well was collected on standard filter microplates (Unifilter ${ }^{\mathrm{TM}}$ GF/B, Perkin Elmer) and washed using a cell harvester (Filtermate $^{\mathrm{TM}}$ Cell Harvester, Packard, Meriden, NJ). Filter microplates were dried and $25 \mu \mathrm{l}$ of scintillation cocktail (Microscint $^{\mathrm{TM}} \mathrm{O}$, Perkin Elmer) was placed in each well. Radioactivity incorporated (in counts per minute, cpm) by the parasites was measured using a scintillation counter (Top Count ${ }^{\mathrm{TM}}$, Perkin Elmer).

\section{Drug susceptibility assays}

The isotopic micro drug susceptibility test used in this study was performed as described previously [23]. The $50 \%$ inhibitory concentration $\left(\mathrm{IC}_{50}\right)$, i.e. the drug concentration corresponding to $50 \%$ of the uptake of $\left[{ }^{3} \mathrm{H}\right]-$ hypoxanthine by the parasites in drug-free control wells, was determined by nonlinear regression analysis of log dose-response curves. Data were analyzed after logarithmic transformation and expressed as the geometric mean $\mathrm{IC}_{50}$ with $95 \%$ confidence intervals. The cut-off value for in vitro resistance to chloroquine is $100 \mathrm{nM}$ [24].

\section{Statistical analysis}

The different results were analyzed with the software STATA 9.0 using a Chi-square test for related samples, a Student's T test or a Wilcoxon signed-rank test (as needed) for related samples. Differences were considered statistically significant when $\mathrm{p}<0.05$.

\section{Results}

In order to determine the effect of oxygen on asexual blood stages of $P$. falciparum, synchronous cultures of 3D7 were exposed to 5, 10 and $21 \% \mathrm{O}_{2}$ during two cycles of parasites. As shown in Figure 1A, there were no significant difference between parasitaemia or parasite stage distribution under 5 and $10 \% \mathrm{O}_{2}$ during all the experiment. On the contrary, from $35 \mathrm{~h}$ to the rest of experimental points, a significant difference between parasite stages was observed (Figure 2), for example at $40 \mathrm{~h}$, there were $42 \%$ of rings and $44.9 \%$ of schizonts under $5 \% \mathrm{O}_{2}$ and $21.7 \%$ of rings and $67.6 \%$ of schizonts under $21 \% \mathrm{O}_{2}$ ( $\mathrm{p}<0.001$, Chi-square test). After the complete reinvasion around 60 $\mathrm{h}$, parasitaemia were the same in the three experimental conditions and no morphologic alteration were observed by light microscopy (Figures $3 \mathrm{~A}$ and $3 \mathrm{~B}$ ). These results have shown that parasite exposure under $21 \% \mathrm{O}_{2}$ had no lethal effect on parasites, but increased the length of schizogony. Moreover, only mature trophozoïtes and schizonts were susceptible to an effect of exposure to $21 \% \mathrm{O}_{2}$ (Figure 4).

The delay was also observed with W2 clone (Figure 1B), with a briefer schizogony ( 8 hours for W2 and 11 hours 3D7) and a higher multiplication index for W2 (\% of infected red blood cells by rings after reinvasion/\% of infected red blood cells by rings at the beginning of the previous cycle), (8 for W2 and 3 for 3D7).

No significant difference were observed in tritiated hypoxanthine uptake between 10 and $21 \% \mathrm{O}_{2}$ with the two clones 3D7 and W2 (Figures 5A and 5B), ( $p=0.087$ and $\mathrm{p}=0.76$ respectively). The maximum of incorporation (around 2,500 cpm with 3D7 and 4,500 cpm with W2) was achieved at 50 hours with a steady-state until 60 hours for 3D7 and W2 in the two experimental conditions. $3 \mathrm{D} 7$ and $\mathrm{W} 2$ chloroquine $\mathrm{IC}_{50}$ were evaluated under 5, 10 and $21 \% \mathrm{O}_{2}$ (three experiments). No significant difference were observed with $3 \mathrm{D} 7$, the $\mathrm{IC}_{50}$ were $15.8 \mathrm{nM}$ [10.8-20.7], $14.1 \mathrm{nM}$ [12.4-16.9], $17.6 \mathrm{nM}$ [14.1-21.1] under $5 \% \mathrm{O}_{2}, 10 \% \mathrm{O}_{2}$ and $21 \% \mathrm{O}_{2}$ respectively. On the contrary, with $\mathrm{W} 2$ clone, $\mathrm{IC}_{50}$ under $21 \% \mathrm{O}_{2}$ was significantly lower than $\mathrm{IC}_{50}$ under $5 \% \mathrm{O}_{2}$ and $10 \%$ $\mathrm{O}_{2}, 83.3 \mathrm{nM}[15-168], 299$ [228-369] and 277 [192322 ] respectively ( $\mathrm{p}<0.05$, Student's T test).

One hundred and thirty six Plasmodium falciparum isolates were used to evaluate chloroquine susceptibility at $10 \%$ $\mathrm{O}_{2}$ and $21 \% \mathrm{O}_{2}$. Three tests at $10 \% \mathrm{O}_{2}$ and 13 tests at $21 \%$ $\mathrm{O}_{2}$ were not interpretable, because of lack of significant difference in cpm between control-wells and higher chloroquine concentration wells. Chloroquine susceptibility 


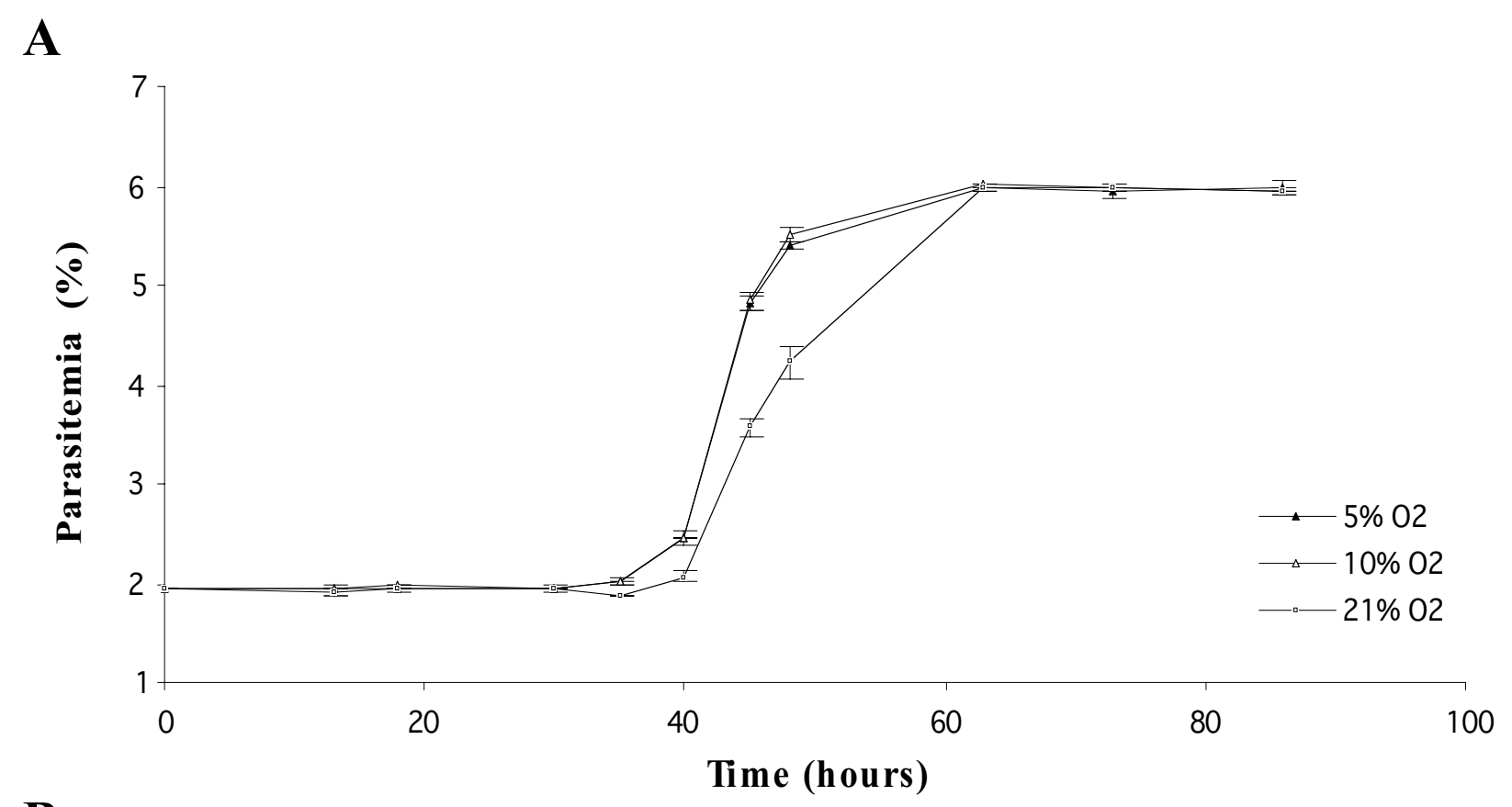

B

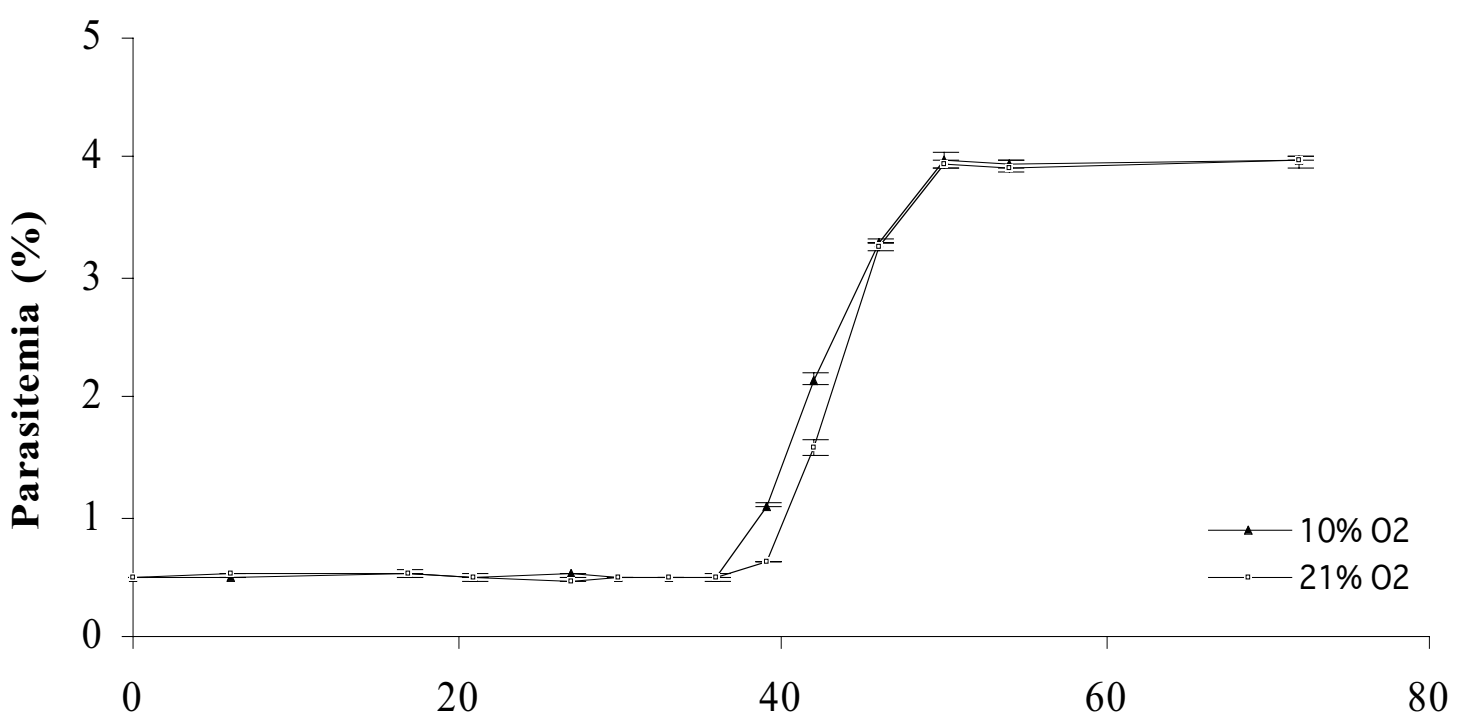

Time (hours)

\section{Figure I}

Evolution of asexual parasitaemia of synchronous cultures of Plasmodium falciparum under different oxygen tensions. Each point represents the mean \pm standard deviation of three experiments. A: 3D7 clone. B: W2 clone.

of 120 isolates was finally tested at 10 and $21 \% \mathrm{O}_{2}$ (Figure $6 \mathrm{~A})$. The differences between the chloroquine $\mathrm{IC}_{50}$ of the 120 isolates at $10 \% \mathrm{O}_{2}$ and at $21 \% \mathrm{O}_{2}$ were statistically significant ( $\mathrm{p}<0.0001$, Wilcoxon signed-rank test), means of $173.5 \mathrm{nM}$ with a standard deviation of 168.4 and $121.5 \mathrm{nM}$ with a standard deviation of 106.7 respectively. The median and interquartile (Q25\% \& Q75\%) values of the chloroquine $\mathrm{IC}_{50}$ at $10 \% \mathrm{O}_{2}$ and $\mathrm{IC}_{50}$ at $21 \%$ $\mathrm{O}_{2}$ of the 120 isolates were respectively $127 \mathrm{nM}, 30 \mathrm{nM}$, $258 \mathrm{nM}$ at $10 \% \mathrm{O}_{2}$ and $85.9 \mathrm{nM}, 36 \mathrm{nM}, 168 \mathrm{nM}$ at $21 \%$ 


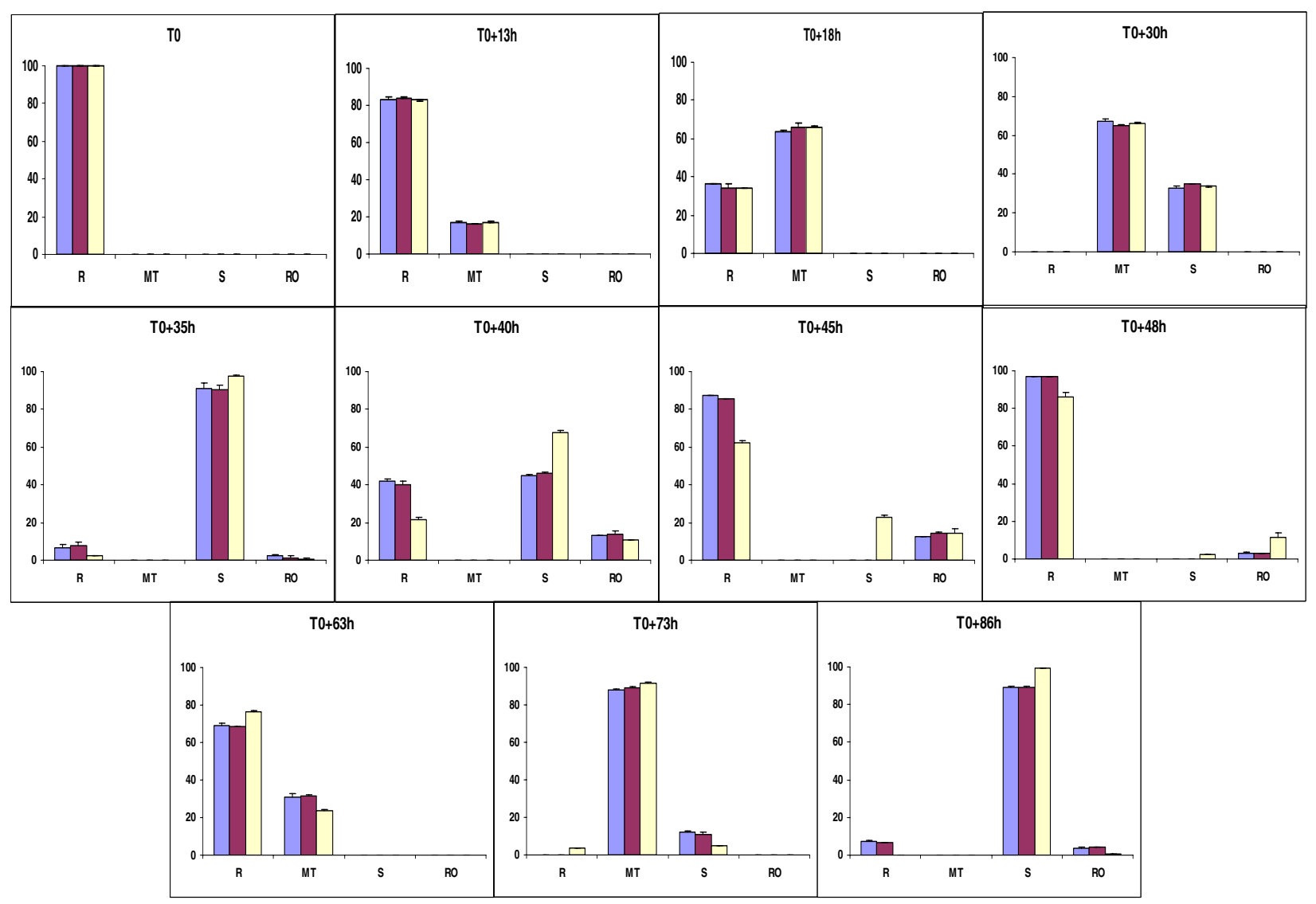

\section{Figure 2}

Percentages evolution of asexual stages of synchronous culture of 3D7 Plasmodium falciparum clone under different oxygen tensions during 86 hours. Each percentage represents the mean \pm standard deviation of three experiments. R: Ring. MT: Mature Trophozoïte: S: Schizont. RO: Rosace. Blue histograms correspond to $5 \% \mathrm{O}_{2}$; Purple histograms correspond to $10 \% \mathrm{O}_{2}$. Yellow histograms correspond to $21 \% \mathrm{O}_{2}$.

$\mathrm{O}_{2}$. In particular of interest, $52.5 \%$ of isolates had chloroquine $\mathrm{IC}_{50}>100 \mathrm{nM}$ at $10 \% \mathrm{O}_{2}$ although $42.5 \%$ of the same isolates had chloroquine $\mathrm{IC}_{50}>100 \mathrm{nM}$ at $21 \% \mathrm{O}_{2}$. Moreover, among the 63 isolates which had chloroquine $\mathrm{IC}_{50}>100 \mathrm{nM}$ at $10 \% \mathrm{O}_{2}, 17$ had chloroquine $\mathrm{IC}_{50}<100$ $\mathrm{nM}$ at $21 \% \mathrm{O}_{2}$ (Figure 6B) (i.e. 1/3) although five isolates only had chloroquine $\mathrm{IC}_{50}>100 \mathrm{nM}$ at $21 \% \mathrm{O}_{2}$ among the 57 isolates which had chloroquine $\mathrm{IC}_{50}<100 \mathrm{nM}$ at $10 \% \mathrm{O}_{2}$ (Table 1), (Chi-square test for paired samples, $\mathrm{p}$ $<0.025)$.

There were no significant difference between the observed control cpm at 10 (mean 12,607, standard deviation 13,425 ) and $21 \% \mathrm{O}_{2}$ (mean 13,302, standard deviation $14,662)$.

\section{Discussion}

The first works about oxygen effects on P. falciparum asynchronous cultures [17] had shown that microaerophilic environment allowed an optimal development of parasites. Their growth was impossible in strict anaerobic conditions. $P$. falciparum possesses a functional mitochondrial respiratory chain with oxygen consumption [25]. It has been shown that there is some protector effect of $\mathrm{CO}_{2}$ at high oxygen concentration [17] through the medium pH which stability (between 7.2 et 7.45 ) is required for parasite growth [26]. The analysis of the different parasites stages distribution according to the time and the oxygen concentration has allowed us to reveal a possible slow down of cellular cycle without morphologic alteration of parasites under $21 \% \mathrm{O}_{2}$. 
A

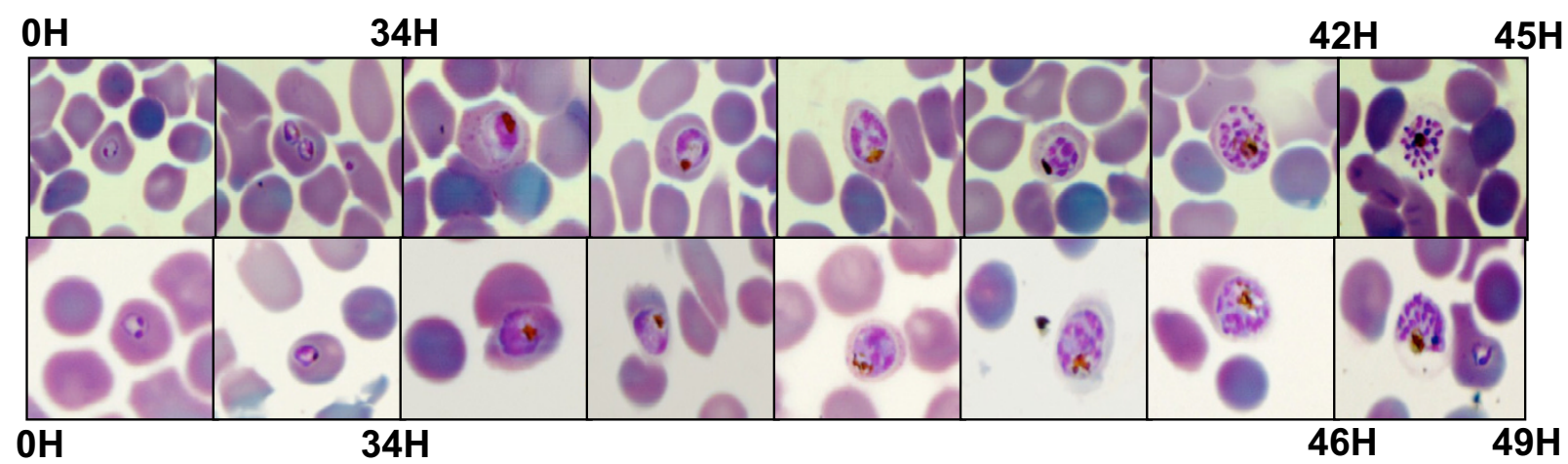

B

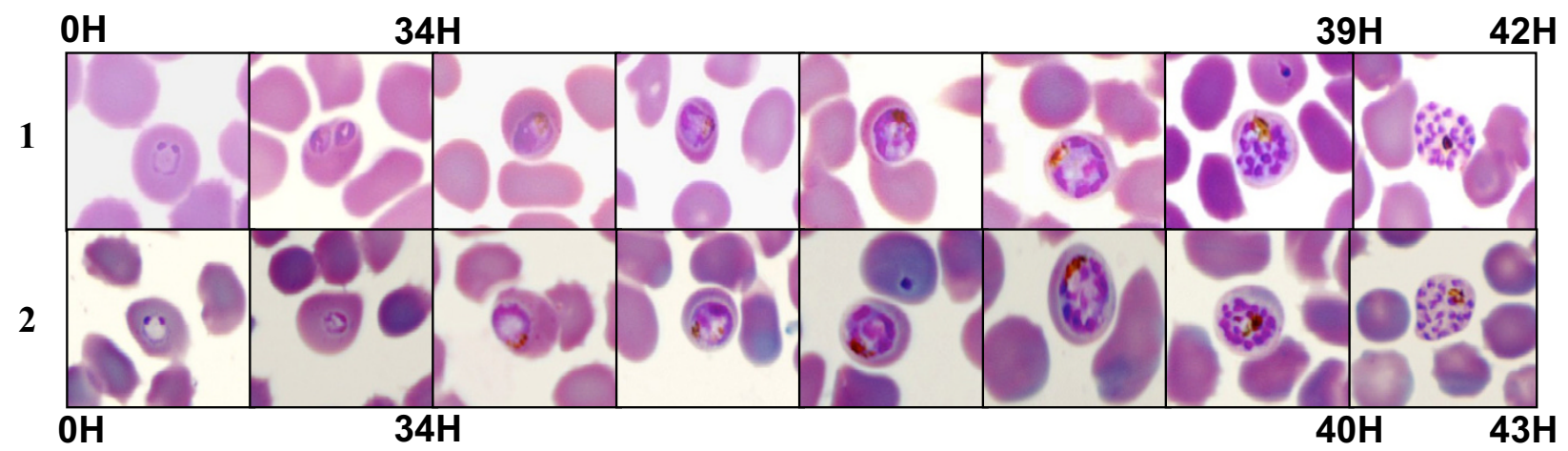

Figure 3

Cell cycle evolution of asexual blood stages of Plasmodium falciparum. A: 3D7 clone. B: W2 clone. I: $5 \% \mathrm{O}_{2}$. 2: $21 \%$ $\mathrm{O}_{2}$.

In the present study, the exposure to $21 \% \mathrm{O}_{2}$ did not change parasitaemia growth rate after complete reinvasion. Previous studies [27] had shown the same absence of oxygen effect on synchronous cultures parasitaemia during four days. Here, it has been shown that the exposure of 3D7 and W2 P. falciparum clones to $21 \% \mathrm{O}_{2}$ had parasitostatic effect by lengthening the schizogony. Mature stages had a particular susceptibility to high oxygen concentration. Moreover, these results justified to test drug susceptibility after a 60 hours period of incubation with $\left[{ }^{3} \mathrm{H}\right]$-hypoxanthine. At the end of trophozoïtes stage, DNA replication begins and is followed by a succession of $\mathrm{S}$ phases during the schizogony [28]. Under $21 \% \mathrm{O}_{2}$, the nucleic acids synthesis decreased from 30 hours for the two $P$. falciparum clones comparing to $5 \% \mathrm{O}_{2}$ exposure. Under $5 \% \mathrm{O}_{2}$, a low $\left[{ }^{3} \mathrm{H}\right]$-hypoxanthine incorporation took place for the first twenty hours, probably corresponding to RNA synthesis in rings, followed by an increase between 20 and 30 hours in possible relation with the beginning of DNA replication at late tropho-

Table I: Repartition of drug susceptibility of Plasmodium falciparum isolates at $10 \% \mathrm{O}_{2}$ and $21 \% \mathrm{O}_{2}$.

\begin{tabular}{|c|c|c|c|}
\hline & & \multicolumn{2}{|c|}{$21 \% \mathrm{O}_{2}$} \\
\hline & & $C Q^{a} \mid C_{50}{ }^{b}<100 n M$ & $\mathrm{CQ} I C_{50}>100 \mathrm{nM}$ \\
\hline $10 \% \mathrm{O}_{2}$ & $\begin{array}{l}C Q I C_{50}<100 \mathrm{nM} \\
C Q I C_{50}>100 \mathrm{nM}\end{array}$ & $\begin{array}{l}52 \\
17\end{array}$ & $\begin{array}{c}5 \\
46\end{array}$ \\
\hline
\end{tabular}

a CQ: chloroquine.

${ }^{\mathrm{b}} \mathrm{IC}_{50}$ : inhibitory concentration $50 \%(\mathrm{nM})$. 


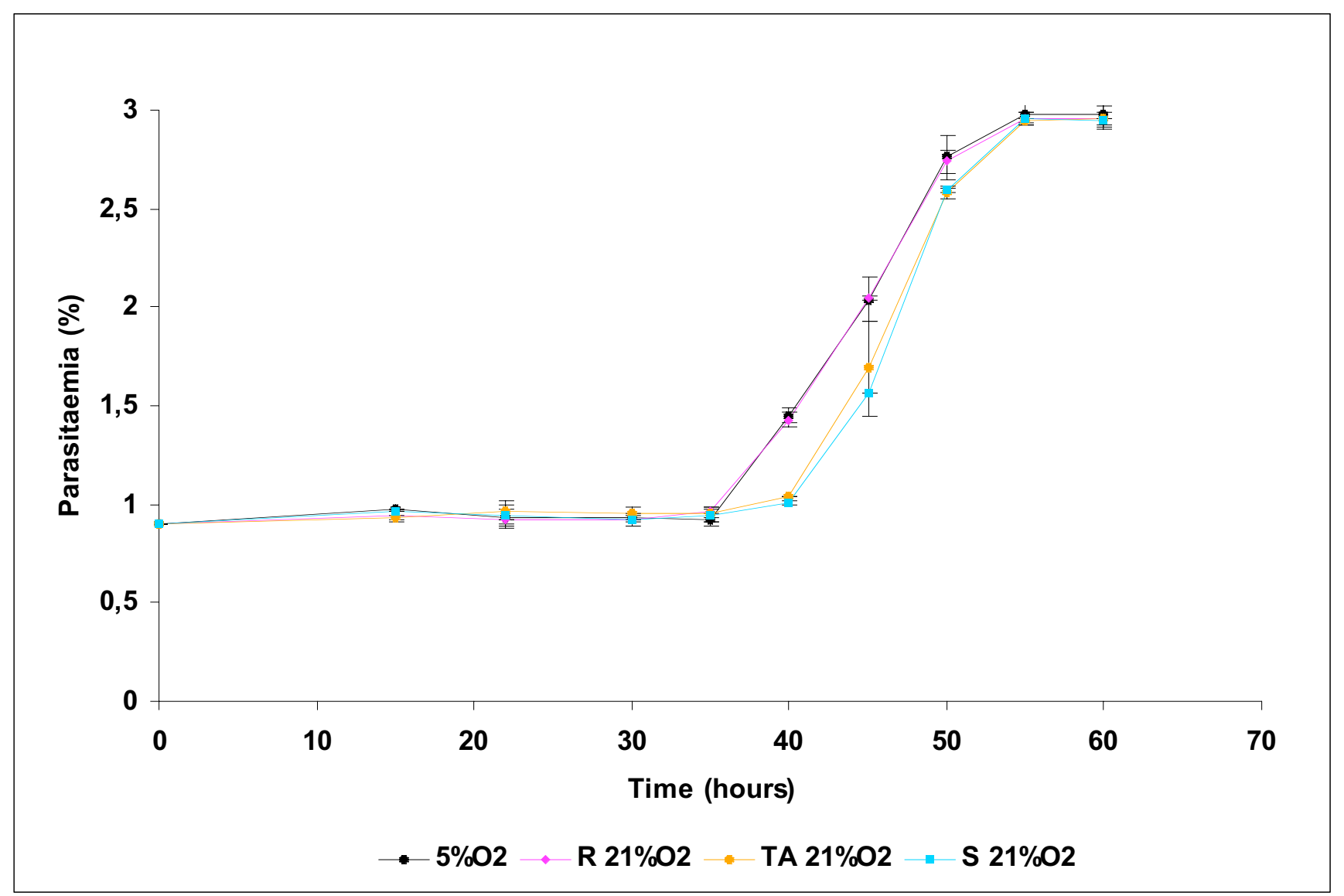

Figure 4

Evolution of asexual parasitaemia of synchronous cultures of Plasmodium falciparum exposed to $21 \% \mathrm{O}_{2}$ during ten hours at ring, trophozoïte or schizont stage. Each point represents the mean \pm standard deviation of three experiments.

zoïtes stage [29]. Between 30 and 40 hours, during schizogony, DNA synthesis increased and the peak was achieved at 50 hours [30].

In the present study, the chloroquine $\mathrm{IC}_{50}$ at $10 \% \mathrm{O}_{2}$ were significantly higher than those at $21 \% \mathrm{O}_{2}$. A previous study did not show oxygen dependent effects of chloroquine on P. falciparum in culture [31], but in that experiment only four strains were tested. In the present work, among the 63 isolates which had chloroquine $\mathrm{IC}_{50}>100$ $\mathrm{nM}$ at $10 \% \mathrm{O}_{2}, 17$ had chloroquine $\mathrm{IC}_{50}<100 \mathrm{nM}$ at $21 \%$ $\mathrm{O}_{2}$. The effect of gas mixture on the results of chloroquine chemosusceptibility should led different laboratories involved in malaria resistance survey to adapt a resistance threshold for each gas mixture or to use the same conditions to perform isotopic microtests.

\section{Conclusion}

Several factors influencing the results of the chemosusceptibility tests (the initial parasitaemia, the haematocrit, the time of incubation, the time point when $\left[{ }^{3} \mathrm{H}\right]$-hypoxanthine is added, the use of serum substitutes) have already been investigated by Basco [15,32]. The present data suggest the importance of the gas mixture on isotopic microtest results for chloroquine. Further studies are needed to evaluate gas mixture impact on isolates susceptibility to other antimalarial compounds and their correlation with molecular markers of resistance and in vivo evaluation of drug efficacy. Other investigations about the preparation of drug solutions, the storage of pre-dosed culture plates are required before in vitro drug sensitivity assay can become a standardized tool for laboratories to validate the threshold for resistance in respect to the clinical responses and molecular markers.

\section{Conflict of interest}

The author(s) declare that they have no competing interests. 
A
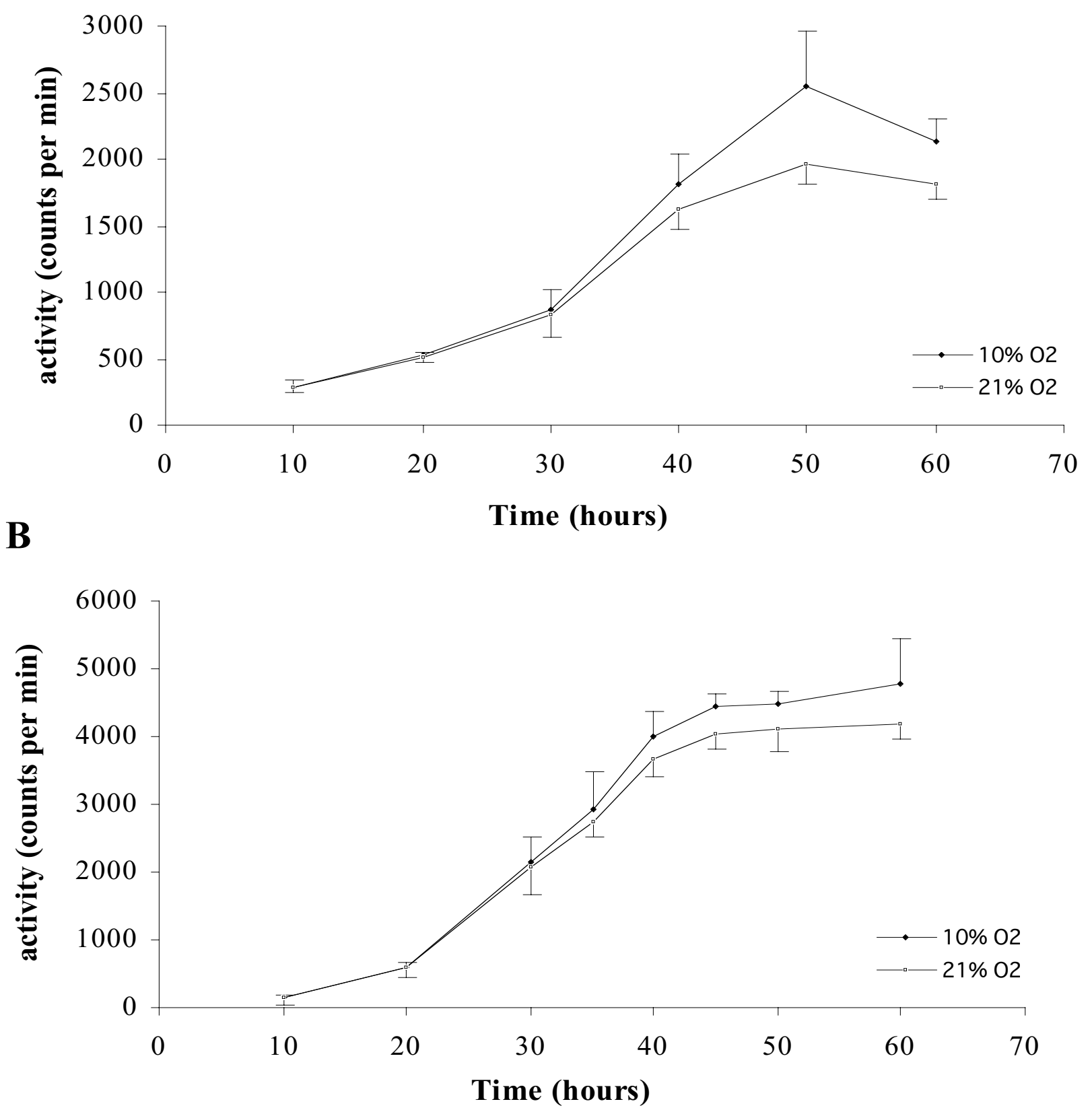

\section{Figure 5}

Tritiated hypoxanthine uptake of synchronous Plasmodium falciparum cultures under $10 \% \mathrm{O}_{2}$ and $21 \% \mathrm{O}_{2}$. Each point represents the mean \pm standard deviation of three experiments. A: 3D7 clone. B: W2 clone.

\section{Authors' contributions}

SB contributed to the design and execution of the study, data analysis and prepared the first draft of the manuscript. PP contributed to the data collect and drafting of the manuscript. TF contributed to the design of the study and drafting of the manuscript. MMF contributed to the execution of the study and writing of the manuscript. EB contributed to the execution of the study. JM contributed 
A

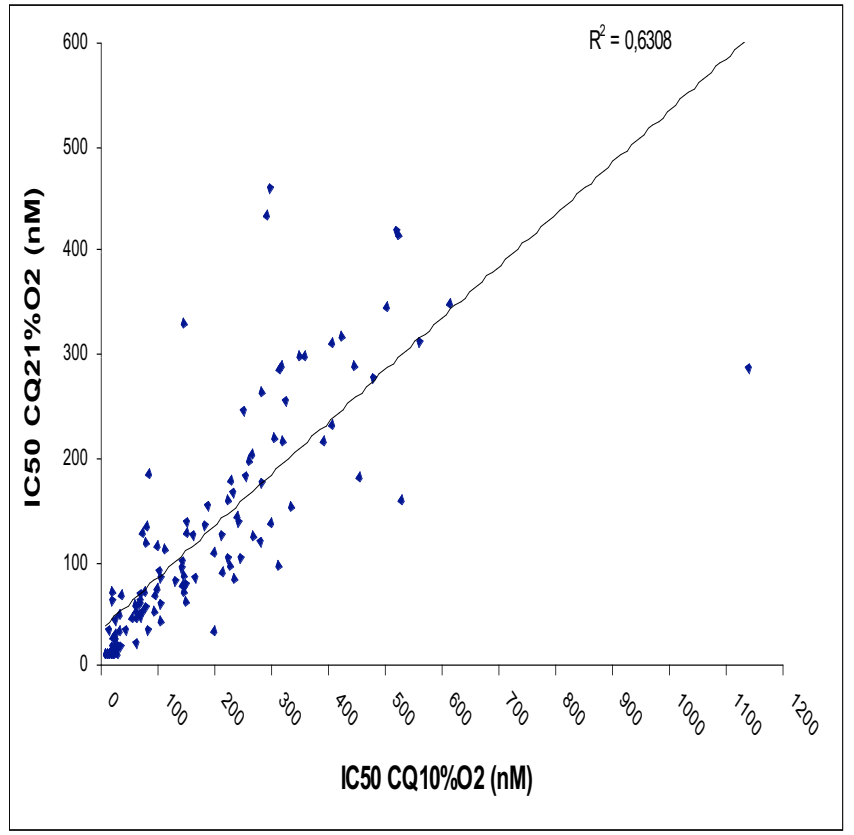

B

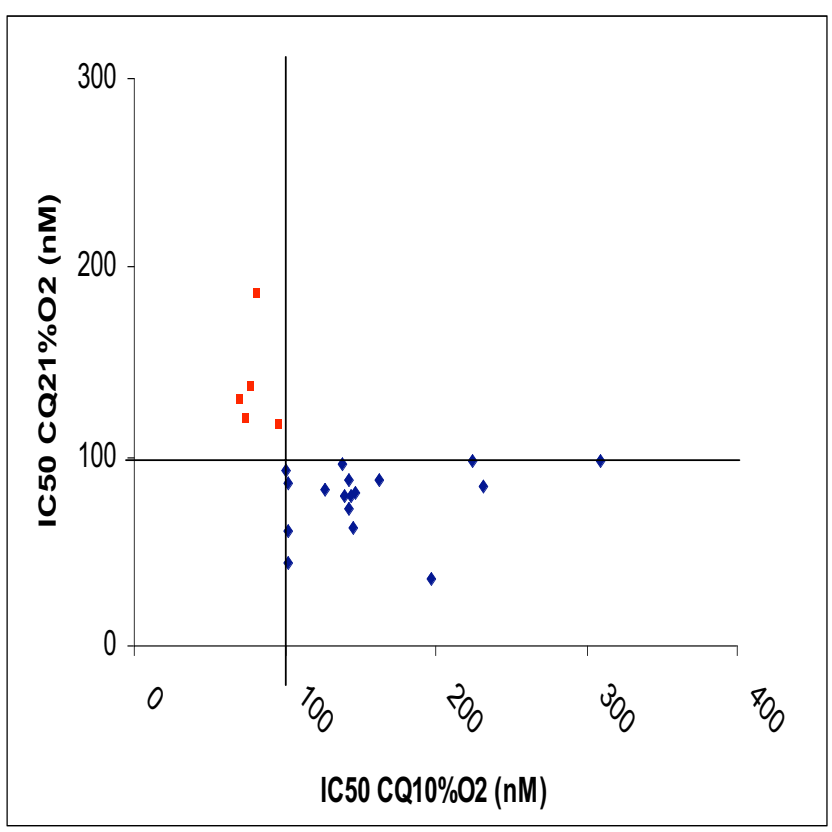

\section{Figure 6}

Chemosusceptibility of Plasmodium falciparum isolates to chloroquine under $10 \% \mathrm{O}_{2}$ and $21 \% \mathrm{O}_{2}$. A: chloroquine $\mathrm{IC}_{50}$ of $\mathrm{I} 20$ isolates. B: red plots corresponds to isolates with a switch from susceptible to chloroquine at $10 \% \mathrm{O}_{2}$ to resistant at $21 \% \mathrm{O}_{2}$; blue plots corresponds to isolates with a switch from resistant at $10 \% \mathrm{O}_{2}$ to susceptible at $21 \% \mathrm{O}_{2}$.

to the execution of the study. JPD contributed to the data collect and the intellectual content of the manuscript. DP contributed to the study design. PM contributed to the data collect and the intellectual content of the manuscript. CR contributed to the study design as well as data analysis and writing of the manuscript. BP contributed to the study design, data analysis and writing of the manuscript.

\section{Disclaimer}

The views and opinions are those of the authors and do not purport to represent those of the French Ministry of Defense.

\section{Acknowledgements}

We thank the Parasitology staff of the Institut de Médecine Tropicale du Service de Santé des Armées for technical assistance. This work was supported by the French Ministry of Defense.

\section{References}

I. Snow RW, Guerra CA, Noor AM, Myint HY, Hay SI: The global distribution of clinical episodes of Plasmodium falciparum malaria. Nature 2005, 434(7030):2 I4-2 I7.

2. Wernsdorfer WH: The development and spread of drugresistant malaria. Parasitol Today I99I, 7(I I):297-303.

3. Trape JF, Pison G, Spiegel A, Enel C, Rogier C: Combating malaria in Africa. Trends Parasitol 2002, 18(5):224-230.

4. WHO: Susceptibility of Plasmodium falciparum to antimalarial drugs. Reports on global monitoring 1996-2004. in WHO/ HTM/MAL/2005.I I 03 Geneva: WHO 2005:.
5. Le Bras J, Musset L, Clain J: Antimalarial drug resistance. Med Mal Infect 2006, 36(8):40।-405.

6. Desjardins RE, Canfield CJ, Haynes JD, Chulay JD: Quantitative assessment of antimalarial activity in vitro by a semiautomated microdilution technique. Antimicrob Agents Chemother 1979, 16(6):710-718.

7. WHO: In vitro micro-test (Mark III) for the assessment of the response of Plasmodium falciparum to chloroquine, mefloquine, quinine, amodiaquine, sulfadoxine/pyrimethamine and artemisinin. In WHO/CTD/MAL/97.20 Rev 22001. Geneva: WHO; 200I.:.

8. Rieckmann KH, Campbell GH, Sax LJ, Mrema JE: Drug sensitivity of plasmodium falciparum. An in-vitro microtechnique. Lancet 1978, I(8054):22-23.

9. Wernsdorfer $\mathrm{WH}$ : Field evaluation of drug resistance in malaria. In vitro micro-test. Acta Trop 1980, 37(3):222-227.

10. Contreras CE, Rivas MA, Dominguez J, Charris J, Palacios M, Bianco $\mathrm{NE}$, Blanca I: Stage-specific activity of potential antimalarial compounds measured in vitro by flow cytometry in comparison to optical microscopy and hypoxanthine uptake. Mem Inst Oswaldo Cruz 2004, 99(2): I79-184.

II. Noedl H, Wernsdorfer WH, Miller RS, Wongsrichanalai C: Histidine-rich protein II: a novel approach to malaria drug sensitivity testing. Antimicrob Agents Chemother 2002, 46(6): I658-I 664.

12. Noedl H, Bronnert J, Yingyuen K, Attlmayr B, Kollaritsch H, Fukuda M: Simple histidine-rich protein 2 double-site sandwich enzyme-linked immunosorbent assay for use in malaria drug sensitivity testing. Antimicrob Agents Chemother 2005, 49(8):3575-3577.

13. Druilhe P, Moreno A, Blanc C, Brasseur PH, Jacquier P: A colorimetric in vitro drug sensitivity assay for Plasmodium falciparum based on a highly sensitive double-site lactate dehydrogenase antigen-capture enzyme-linked immunosorbent assay. Am J Trop Med Hyg 200I, 64(5-6):233-24I.

14. Dieng T, Bah IB, Ndiaye PM, Diallo I, Diop BM, Brasseur P, Mboup S, Wirth D, Ndir O: In vitro evaluation of the sensitivity of Plas- 
modium falciparum to chloroquine using the deli-microtest in region of Dakar, Senegal. Med Trop (Mars) 2005, 65(6):580-583.

15. Basco LK: Molecular epidemiology of malaria in cameroon. $X X$. Experimental studies on various factors of in vitro drug sensitivity assays using fresh isolates of Plasmodium falciparum. Am J Trop Med Hyg 2004, 70(5):474-480.

16. Pradines B, Spiegel A, Rogier C, Tall A, Mosnier J, Fusai T, Trape JF, Parzy D: Antibiotics for prophylaxis of Plasmodium falciparum infections: in vitro activity of doxycycline against Senegalese isolates. Am J Trop Med Hyg 2000, 62(1):82-85.

17. Scheibel LW, Ashton SH, Trager W: Plasmodium falciparum: microaerophilic requirements in human red blood cells. Exp Parasitol 1979, 47(3):410-4|8.

18. Parola P, Soula G, Gazin P, Foucault C, Delmont J, Brouqui P: Fever in travelers returning from tropical areas: prospective observational study of 613 cases hospitalised in Marseilles, France, 1999-2003. Travel Med Infect Dis 2006, 4(2):6I-70.

19. Trager W, Jensen JB: Human malaria parasites in continuous culture. Science 1976, 193(4254):673-675.

20. Lambros C, Vanderberg JP: Synchronization of Plasmodium falciparum erythrocytic stages in culture. J Parasitol 1979, 65(3):4|8-420.

21. Bogreau H, Renaud F, Bouchiba H, Durand P, Assi SB, Henry MC, Garnotel E, Pradines B, Fusai T, Wade B, Adehossi E, Parola P, Kamil MA, Puijalon $O$, Rogier $C$ : Genetic diversity and structure of African Plasmodium falciparum populations in urban and rural areas. Am J Trop Med Hyg 2006, 74(6):953-959.

22. Henry M, Diallo I, Bordes J, Ka S, Pradines B, Diatta B, M'Baye PS, Sane M, Thiam M, Gueye PM, Wade B, Touze JE, Debonne JM, Rogier C, Fusai T: Urban malaria in Dakar, Senegal: chemosusceptibility and genetic diversity of Plasmodium falciparum isolates. Am J Trop Med Hyg 2006, 75(1): 146-15I.

23. Pradines B, Hovette P, Fusai T, Atanda HL, Baret E, Cheval P, Mosnier J, Callec A, Cren J, Amalvict R, Gardair JP, Rogier C: Prevalence of in vitro resistance to eleven standard or new antimalarial drugs among Plasmodium falciparum isolates from PointeNoire, Republic of the Congo. J Clin Microbiol 2006, 44(7):2404-2408.

24. Le Bras J, Ringwald P: Plasmodium falciparum chemoresistance. The situation in Africa in 1989. Med Trop (Mars) 1990, 50(I): $11-16$.

25. Krungkrai J, Burat D, Kudan S, Krungkrai S, Prapunwattana P: Mitochondrial oxygen consumption in asexual and sexual blood stages of the human malarial parasite, Plasmodium falciparum. Southeast Asian J Trop Med Public Health 1999, 30(4):636-642.

26. Jensen MD, Conley M, Helstowski LD: Culture of Plasmodium falciparum: the role of $\mathrm{pH}$, glucose, and lactate. J Parasitol 1983, 69(6): 1060-1067.

27. Miyagami T, Waki S: In vitro cultivation of Plasmodium falciparum under aerobic atmosphere in a CO2 incubator. J Parasitol I985, 7 I(2):262-263.

28. Doerig C CD Kappes B, Matthews K: The cell cycle in protozoan parasites. In Progress in Cell Cycle Research Volume Volume 4. Edited by: Edited by Meijer L JADB. New York, Kluwer Academic and Plenum; 2000:163-183.

29. Gritzmacher CA, Reese RT: Protein and nucleic acid synthesis during synchronized growth of Plasmodium falciparum. J Bacteriol 1984, 160(3): I |65-1 I67.

30. Inselburg J, Banyal HS: Synthesis of DNA during the asexual cycle of Plasmodium falciparum in culture. Mol Biochem Parasitol 1984, I O(I):79-87.

31. Divo AA, Geary TG, Jensen JB: Oxygen- and time-dependent effects of antibiotics and selected mitochondrial inhibitors on Plasmodium falciparum in culture. Antimicrob Agents Chemother 1985, 27(I):21-27.

32. Basco LK: Molecular epidemiology of malaria in Cameroon. XXIII. Experimental studies on serum substitutes and alternative culture media for in vitro drug sensitivity assays using clinical isolates of Plasmodium falciparum. Am J Trop Med Hyg 2006, 75:777-782 Publish with Biomed Central and every
scientist can read your work free of charge

"BioMed Central will be the most significant development for disseminating the results of biomedical research in our lifetime. "

Sir Paul Nurse, Cancer Research UK

Your research papers will be:

- available free of charge to the entire biomedical community

- peer reviewed and published immediately upon acceptance

- cited in PubMed and archived on PubMed Central

- yours - you keep the copyright

Submit your manuscript here:

http://www.biomedcentral.com/info/publishing_adv.asp
BioMedcentral 